\title{
A VAR Analysis Of US-China Economic Linkages
}

\author{
Dene T. Hurley, Lehman College-CUNY, USA
}

\begin{abstract}
An increase in Chinese purchases of U.S. treasury securities in parallel with China's commitment to maintain the value of the Yuan have been blamed in recent years for the divergence of the U.S. long-term and short-term interest rates. Results of the VECM, variance decomposition and impulse response analyses provided support for the growing speculations that growing Chinese demand for U.S. securities played a significant role in keeping the 10-year Treasury bill rate low while keeping the Yuan weak relative to the U.S. dollar. As for the U.S. long-term and short-term interest rates, the causality was found to run from the 10-year Treasury bill yield to the s rate which helps to explain why rising short-term rate in the U.S. since mid-2004 had little or no impact on the long-term rate.
\end{abstract}

Keywords: Chinese Yuan, purchases of U.S. treasury securities, interest rates

\section{INTRODUCTION}

¿ $\mathrm{n}$ recent years, China has been facing mounting international pressure, particularly from the U.S., to allow its currency to float freely and appreciate in value. This came on the heels of its rising foreign exchange reserves which stemmed from an impressive export performance and strong net inflows of foreign capital, including speculative inflows. By 2007, China's foreign exchange reserve holdings rose to over US\$ 1.53 trillion, constituting $47.1 \%$ of its GDP, with the U.S. securities accounting for much of this holding (Morrison and Labonte 2008$)^{1}$. This is not surprising since the U.S. bilateral trade deficit with China has been growing steadily, reaching over US $\$ 256$ billions by 2007.

The rapid expansion in China's holding of foreign reserves in general has been attributed to that nation's effort to maintain a competitive edge in the export market by keeping its exchange rates relatively fixed (Krugman 2005, Shostak 2005). In July 2005, yielding to international pressure, China revalued the Yuan by $2.1 \%$ against the U.S. dollar, and a managed float regime was implemented under which the Yuan was pegged to a basket of currencies with plans to allow its value to move in a tight $0.3 \%$ daily band against the U.S. dollar. Despite these exchange rate adjustments, there has been continued pressure on China to allow its currency to appreciate further to help fix its trade imbalance with the world. In the U.S., concerns have grown that China's exchange rate policy may be hurting U.S. long-term growth prospects by eroding its manufacturing base (Navarro 2009). Furthermore, China's strong demand for U.S. Treasuries is claimed to have contributed towards keeping their prices high and yields low. Between mid-2004 and 2007, the U.S. long-term interest rate declined even as the U.S. short-term rates surged and stayed high, creating a divergence in the path between those two interest rates through $2007^{2}$. This low long-term rate helped to fuel the robust economic expansion in the U.S. through late 2007. Arguments that increased Chinese holdings of U.S. securities may not be sustainable have emerged more recently, particularly in light of the recent economic turmoil in the U.S. This, combined with anticipation of further appreciation of the Yuan, has given rise to fears and speculations over the likely impact on the U.S. and in particular on the interest

\footnotetext{
${ }^{1}$ In 2006, China overtook Japan to become the world's largest holder of foreign reserves, and it accounted for $24 \%$ of the world's foreign exchange reserves. Further, its reserves grew the fastest from 2007-2007. (Morrison and Labonte, 2008).

${ }^{2}$ This behavior of the long-term interest rates was referred to as a "conundrum" by the Federal Reserve Chairman Greenspan during the congressional testimony on February 16, 2005 (Wu 2005)
} 
rates. Attempts by China to reduce its holdings of U.S. securities will likely boost the U.S. long-term rates which should negatively impact investment spending and other interest-sensitive spending in the U.S.

In spite of tightening economic and financial ties between China and the U.S. in recent years, there is little or no empirical study on their relationships in the area of international finance ${ }^{3}$. Most of the studies have focused on Chinese currency and trade issues. For example, Chou (2000), Jin (2003), and Narayan and Smyth (2004) focused on the relationship between the Chinese currency and trade while Lu and Zhang (2003) examined the linkages between the Yuan and China's inflation. Others such as Moosa (2008), Zhang (2001) and Xu (2000) were concerned with exchange rate regime, policy and the misalignment of the Yuan.

The goal of this paper is to investigate the relationship between the Chinese Yuan-Dollar exchange rate, China's demand for U.S. Treasury securities and the U.S. long and short-term interest rates using the vector autogressive (VAR) tools including causality, variance decomposition and impulse response analysis. In particular, it will focus on the influence of the Chinese exchange rate and purchases of U.S. securities on the U.S. long-term rates. The degree of influence of the U.S. short-term interest rates on the long-term rate structures will also be examined which should help shed light on why recent increases in the short-term rates have not helped to lift the U.S. long-term rates. The study covers the period from March 2000 to the May 2008.

The paper consists of four sections. Section one provides a brief background on relationships between the Yuan-Dollar exchange rates, China's holdings of the U.S. securities and the U.S. interest rates. This is followed by an empirical investigation of the linkages between these variables which includes examining their short-term and long-term behaviors and conducting causality tests to help establish the direction of causality between them. Variance decomposition and impulse response functions will provide further insight into the dynamic relationships between the four variables. The last section gives the concluding remarks.

\section{U.S.-CHINA LINKAGES: AN OVERVIEW}

Since June 2004, the U.S. Federal Reserve Bank has been raising the federal funds rate against the backdrop of fears of inflationary pressures stemming from robust economic growth. As shown in Figure 1, from a low one percentage point in early 2004, this interest rate climbed to $5.26 \%$ by early 2007 and stayed close to that rate through almost the end of 2007. Normally, short-term rate increases are accompanied by a comparable rise in the longer term rates for credit cards, car loans, and mortgages. Instead of rising along with the short term rates, long term rates have actually slipped. Figure 1 reveals that the yield on 10-year U.S. Treasury bills, which hit $4.73 \%$ in June 2004, slipped and stayed below 4.6\% through early 2006. Although it rose slightly from that level thereafter, it generally stayed below 5 percent. An influx of foreign savings has emerged as a key explanation behind the relatively low U.S. long-term interest rates. Foreign purchase of U.S. bonds, which normally approximates close to $2 \%$ of the U.S. GDP, reached $7 \%$ by 2007 . China's role in this build-up of foreign savings, especially in relation to its determination to maintain a pegged exchange rate against the U.S. dollar, has received considerable attention recently.

Until 1994, China had multiple exchange rates and its official rate did not reflect the one used in foreign trade and exchange transactions. Prior to the introduction of market reform measures in the late 1970's, China's official exchange rate was overvalued. Following the decentralization of foreign trade in 1978, the overvalued currency was beginning to hurt the export competitiveness of Chinese exporters. Consequently, an internal settlement rate closer to the average cost of earning a U.S. dollar in exports (2.8 Yuan per U.S. dollar) was used in place of the official rate between 1979 and 1984. With the depreciation of the official rate towards the internal settlement rate, the two merged in 1985 . However, the problem was that foreign enterprises had to balance their own exchange rate requirements due to the exchange controls. Thus, regionally based swap markets emerged, and soon local governments and state enterprises also entered these markets to trade their retained foreign exchange transactions. As pointed out by Xu (2000), by 1993, 80\% of foreign exchange transactions were conducted at the

\footnotetext{
${ }^{3}$ This includes studies by Brown et al. (2005) which examined U.S.-China trade relations, while Narayan (2006) looked at the relationship between U.S.-China trade balance and exchange rates. Morrison and Labonte (2008) investigated the Chinese demand for U.S. securities.
} 
swap market rates. Consequently, in 1994, a national foreign exchange market was formed by formally phasing out the official rate and a managed float was adopted, although the float was within a narrow band as the Yuan was pegged to the dollar at 8.28. In July 2005, in response to growing international pressure due to its growing trade surplus with the rest of the world, China revalued the Yuan by $2 \%$ against the U.S. dollar to 8.11, and then pegged it to a basket of currencies with plans to allow its value to move in a tight $0.3 \%$ daily band against the U.S. dollar.

Meanwhile, China's foreign trade has been growing steadily, rising from US\$289 billion in 1995 to 2.173 trillion by 2007. By 2007, its trade surplus with the rest of the world topped $\$ 262.2$ billion with the bulk of this coming from China's exports to the U.S. This was attributed to its still undervalued Yuan which had given an unfair advantage to the Chinese exporters. Figure 2 shows that the U.S. bilateral trade deficit with China, which account for most of China's global trade surplus, more than tripled since 2000 to over $\$ 256$ billion by 2007 , making it the largest trade deficit with the U.S. of any country. As China's foreign exchange reserves swelled from $\$ 169$ billion in 2000 to $\$ 1.53$ trillion by late 2007, U.S. has been borrowing from abroad to finance its growing trade deficit gap (Morrison and Labonte 2008). The People's Bank of China has been purchasing large volumes of U.S. dollar assets, particularly since 2001, as part of its effort to maintain its exchange rate stability. As shown in Table 1, since 1997, China's holding of U.S. treasury securities increased ten-fold, hitting US $\$ 477.6$ billion by 2007; this made up 20\% of the overall foreign holding of U.S. treasury securities. Since 2000, China has surpassed United Kingdom to become the second largest holder of U.S. treasury securities after Japan.

Given these developments and tightening economic and trade ties between China and the U.S., it is hardly surprising that many academics and policy makers (including Browne 2006, Morrison and Labonte 2008, Navarro 2009, Wu 2005) have began to pay closer attention to China's growing influence on the U.S. domestic economy as a possible key explanation behind the low long-term U.S. interest rate structures, which in turn helped to fuel a U.S. housing boom and economic growth in recent years. There are also rising fears and concerns of the likely negative impact on the U.S. economy, should China allows its currency to appreciate or if that nation decides to diversify away from the U.S. security holdings. Further appreciation of the Yuan is anticipated especially if China decides to diversify its reserves from dollar holdings in the future. With three-fourths of its foreign currency reserves in U.S. treasury bills and other dollar denominated assets, China may likely shift some assets to other currencies and diversify its portfolio to protect its reserves from significant changes in the dollar's value, particularly in view of the recent financial turmoil in the U.S. While a stronger Yuan should help improve U.S. bilateral trade relations with China, the increases in U.S long-term interest rates which are projected to accompany this have heightened the fears of further deepening of the ongoing U.S. economic crisis.

\section{METHODOLOGY AND FINDINGS}

This paper analyzes the relationship between the U.S. long and short-term interest rates, the Yuan exchange rate relative to the U.S. dollar and Chinese purchases of U.S. treasury securities for the period covering March 2000 to December 2008. It uses tools employed by VAR analysis - causality, variance decomposition and impulse response - to examine the inter-relationships among the four variables. The Yuan-dollar exchange rate data is obtained from the Federal Reserve Bank of New York while the monthly Chinese purchases of U.S. securities were obtained from the Department of Treasury's TIC data. U.S. short-term and long-term interest yields are represented by the monthly U.S. federal funds rates and 10 year U.S. Treasury bill rates which are published by the U.S. Department of Treasury.

\section{Unit Root And VEC Model}

Prior to evaluating the relationship between the four variables, the unit root test is performed on the log values of the time series data. Both the Dickey-Fuller (ADF) and Phillips-Perron tests were carried out and all series are found to be stationary in first differences at $95 \%$ confidence level. Although the series are nonstationary in level, their linear combination may be cointegrated. This would indicate that in the long-run, they follow a common upward trending behavior and, should shocks drive them apart, common characteristics will bring them back together. As pointed out by Engle and Granger (1987), if cointegration is present, it provides evidence of a close relationship and causal relations between the data series in at least one direction. Prior to performing the cointegration tests, the VAR model in levels is first run to determine the optimal lag length which was found to be 2 
lags, based on the SIC and Akaike information criterion (AIC). The Johansen-Juselius (JJ) cointegration method, which is based on the maximum likelihood estimation of the VAR model, is then used to investigate the long-run relationship. The two likelihood ratio (LR) tests (the trace and maximum eigenvalue tests) help to establish the number of cointegrating vectors, and the results are reported in Table 2. The trace test result suggests the presence of one cointegrating vector at $95 \%$ confidence level but two cointegration vectors at $90 \%$ confidence level. These findings indicate the existence of a long run equilibrium relationship among the variables.

Given that the presence of cointegration points to evidence of causality, causality tests are conducted based on the vector error correction (VEC) method. Unlike the standard Granger causality test, this method considers an additional channel of causation by including the error correction mechanism (ECM) term. This variable, which represents the residuals from the cointegration regression, takes account of the adjustment of the dependent variable to the lagged deviations from the long-run path. Table 3 reports the findings from the VEC model. With the exception of the federal funds rate, the error correction term is statistically significant in all cases although the value was negative for the 10-Year Treasury bill rate and the Chinese purchases of securities only, suggesting that these time series are non-explosive. Since the significance of the ECM term implies the presence of long-term causality, findings here indicate that the federal funds rate, the Yuan-U.S. Dollar exchange rate and the Chinese purchases of U.S treasury securities together exert influences on the 10-year treasury bill yields while the Chinese Yuan's exchange rate is affected by the U.S. short and long-term interest rates and the Chinese purchases of the securities. This latter variable is impacted by both the U.S. interest rate series as well as the Yuan exchange rate. The absolute size of the coefficient of ECM reveals the speed of adjustment towards the long-run equilibrium, and of the four variables, the Chinese Yuan exchange rate adjusts the slowest with $1 \%$ of the adjustment taking place per month. This may be attributed to the managed float exchange rate system of the Yuan which limits its adjustability in general. Meanwhile, the adjustment speed of the Chinese purchases was the fastest. Apart from these long-run causal relations, the joint significance test based on the F-statistics for the VECM models indicates that the short-run causality effects were significant at $1 \%$ level in all cases with the exception of the 10-year Treasury bill interest rates. More specifically, there is evidence of a significant unidirectional causality from the Chinese purchases of the U.S securities to the 10-Year Treasury bill rate and the Yuan's exchange rate as well as from the 10-Year Treasury bill rate to the federal funds rate. Both the long-run and short-term causal relationships are found in only two cases which are the Yuan exchange rates and the Chinese purchases of U.S. securities. In summary, these findings from the VECM models suggest that the purchase of U.S. securities by China plays a significant role in explaining the behavior of the 10-year Treasury bill rates as well as the exchange rate between the two nations. In addition, contrary to the general expectation, the causal relation between the two U.S. interest rates runs only one way, from the 10 -year Treasury bill to the federal funds rate.

\section{Variance Decomposition And Impulse Response Functions}

Variance decomposition and impulse response functions (together known as "innovative accounting' techniques) are employed next to examine the dynamic relationships among the U.S. interest rates, the Yuan-dollar exchange rates and Chinese purchases of U.S. treasury securities. Variance decomposition (VDC) is used to assign the percentage contribution of each innovation in explaining the k-step ahead forecast error variance of each dependent variable (Enders 1995). It provides a means for establishing the relative importance of a shock in each of the data series in explaining other series in this study. An area of particular interest here is to examine the role played by a shock in the Chinese purchases of U.S. securities in explaining the U.S. interest rates, in particular the long-term interest rates which are proxied by the 10-year Treasury bill rates. The Choleski factor is used to normalize the system so that the innovation matrix is diagonal, thereby allowing for experiments in which any variable is independently shocked. The conclusion which may be drawn is often sensitive to the ordering selected; the ordering used in this study is guided by the causality findings from the VECM model discussed earlier which is as follows: Chinese purchases of securities, 10-year Treasury bill rates, federal funds rates and the Yuan-Dollar exchange rates.

The VDC of the four series for forecast horizons of up to 36 months are shown in Table 4 . The larger the number, the stronger the linkage among the data series. In looking at the share of each of the variables in explaining the relative variation of the U.S. 10-year Treasury bill rates, the Chinese purchases of U.S. securities helped to explain a significant portion, rising to over $17 \%$ by the end of 36 months while the U.S. federal funds rates' 
contribution stayed below $2 \%$. Meanwhile, the 10 -year Treasury bill rate was the only variable that explained a significant portion of the forecast variance of its own innovations as well as that of the remaining variables over the 36 months, specifically by the amount of $38 \%$ of the relative variation of the federal funds rate, $33 \%$ of relative variation of the exchange rate and $46 \%$ of variation of the Chinese purchase of the U.S. securities. In addition to the 10-year Treasury bill yield, the Yuan-Dollar exchange rates also had a noteworthy impact on the U.S. short-term interest rate's behavior although its influence was less than that of the Treasury bill rate. As for the relative variation of the Yuan-Dollar exchanges rates, the two U.S. interest rates accounted for almost half of the overall variance with the 10 -Year bill rate picking up a larger percentage (33\%) of the overall shock. While close to half of the innovations in the Chinese purchases of securities are explained by its own past values by the end of 36 months, the 10-year Treasury bill rate also accounted for almost the same portion (46\% of the overall shock of the Chinese purchases).

The following conclusions can be reached from the VDC findings. Firstly, these results provide further evidence for arguments that rising Chinese purchase of U.S. securities may have played a significant role in keeping the U.S. long-term interest rates low. Secondly, despite a slight increase in its role when viewed in terms of the overall magnitude, U.S. short-term rates have had little or no effect on the overall variation of the long-term interest rates, which also helps to confirm the findings by researchers such as Bremnes et al (2001). Meanwhile, the longterm rate appears to play a more significant role in affecting the behavior of the federal funds rate. Thirdly, as expected, U.S. interest rate policies had a notable impact on the exchange rate between the U.S. dollar and the Chinese Yuan. Lastly, the significant contribution of the Chinese demand for U.S. securities as well as the YuanDollar exchange rates in explaining the forecast variance of the U.S. interest yields, in particular that of the longterm rate, reveals the growing vulnerability of the U.S. domestic economy to China's macroeconomic policy (in particular to that nation's exchange rate and trade policies). China's influence is likely to rise further as trade relations between the two countries continue to grow, which should tighten the financial ties between the two nations.

Impulse response function analysis is used to establish the direction and the time path of the response of the endogenous variable to a shock in that variable and other endogenous variables in the model. Figure 3 shows the response of other variables to a one standard deviation shock of each of the four endogenous variables for horizons 1 through 36 months, using the same ordering as the VDC. A striking feature of the response of the 10-year Treasury bill rate is that a shock to the federal funds rate has a negative impact on this long-term rate at the beginning before turning positive in the seventh month. Meanwhile, the negative impact of a shock to Chinese purchases of the securities grows even stronger through the forecast period, accounting for close to $20 \%$ of the response. This notable negative response to the Chinese demand for U.S. securities more than offsets the overall smaller but positive responses to the shocks to the short-term rate and the Yuan-Dollar exchange rates. This finding again validates and further strengthens the argument that the rising Chinese demand for U.S. securities is largely behind the persistence of the low long-term interest rates in the U.S. in recent years even in the midst of the rising shortterm rate. It is also noteworthy that the Yuan-Dollar exchange rates respond positively to a shock in the Chinese purchase of the U.S. securities with a time lag of three months. This supports the recent growing speculation that the rising purchases of U.S. securities by the Chinese is helping to keep the Yuan weak relative to the U.S. Dollar to help boost China's exports with the U.S. In addition, it suggests that should China reduces it demand for these securities, it would take three months for the Yuan-Dollar exchange rate to adjust down or for the value of the U.S. dollar to depreciate relative to the Yuan (or for the Yuan to appreciate against the U.S. dollar). Furthermore, although both the federal funds rate and the 10-year interest rate respond positively after a 2 month time lag to a shock in the Yuan-Dollar exchange rate, the impulse response of the former interest rate is significantly stronger (at $9 \%$ ) compared with less than one percent for the latter interest rate.

Combined with the VDC results, the impulse response results indicate that in the event that the ongoing financial crisis in the U.S. prompts China to reduce its demand for the U.S. securities and allow the value of the Yuan to appreciate relative to the U.S. dollar, an increase the U.S. interest rates will likely follow, which should further add to U.S. economic woes. Lastly, while both the 10-year Treasury rate and the federal funds rate respond positively to each other, the response of the latter to the shock to the former is more spectacular at around $16 \%$ compared with less than $1 \%$ for the response of the 10 -Year bill rate to the shock to the federal funds rate. This suggests that any future increases in the long-term interest rates in the U.S. will likely pull up the short-term rates 
significantly, but the response of the long-term rate to the short-term increase will stay limited, particularly in an economic environment where China's demand for U.S. securities remains strong.

\section{CONCLUSION}

In recent years, along with its booming export trade, China's holding of foreign reserves has climbed at an impressive rate as its demand for U.S. securities also jumped. Speculation has been growing that these developments are part of China's effort to keep the value of its currency weak to help bolster its export trade and economic performance. Meanwhile, in the U.S., in spite of a strong surge in the short-term interest rate, especially since mid2004, the long-term interest rate has declined or stayed low, which has helped to boost the spending (particularly in the housing sector) and, in turn, has fueled an economic boom through late 2007. The divergence in the long and short-term interest rates has led to an increase in the interest in the relationship between the value of the Chinese currency, the Chinese purchases of U.S. securities and the U.S. short and long-term interest rates.

The results of the VECM, variance decomposition, and impulse response analyses on the four variables (Yuan-Dollar exchange rate, Chinese purchase of U.S. securities, 10-year Treasury bill rate and federal funds rate) for the period of the study indicate that the Chinese purchases of U.S. securities had a significant negative effect on the 10-year Treasury yield. This provides evidence to growing speculations that growing demand for U.S. securities may have played a key role in keeping the U.S. long-term rates low in spite of raising short-term interest rates. Meanwhile, the Yuan-Dollar exchange rate is found to have a positive significant response to the Chinese demand for U.S. treasury bills, which again lends support to recent speculations that Chinese holdings of U.S. securities is helping to keep the Chinese Yuan weak to help bolster its booming exports and economic growth. In addition, the impulse response analysis points to a three-month adjustment period for the Yuan-Dollar exchange rate in the event that China cuts back its demand for U.S. securities. As for the U.S. long-term and short-term interest rates, the causality was found to run from the former to the latter rate, which helps to explain why rising short-term rate in the U.S. since mid-2004 has had little or no impact on the long-term rate. Although there is no transmission of impulse from the federal funds rate to the 10-year Treasury bill rate, the former rate responds positively to the shock from the latter rate, suggesting that the short-term rate will likely rise along with the long-term rate increases.

\section{AUTHOR INFORMATION}

Dene T. Hurley is an assistant professor in the Department of Economics and Business at Lehman College - The City University of New York, NY. She obtained her Ph.D. in Economics from Northeastern University, Boston. Hurley's research interests cover international trade and finance. Prior to joining Lehman College, Hurley was the Director of Maritime Research at the New York-based Port Import/Export Reporting Service (PIERS), a division of the Journal of Commerce.

\section{REFERENCES}

1. Barboza, D. (2006) China's trade surplus tripled in 2005, New York Times, January 11.

2. Bremnes, H., Gjerde, O. and Soettem, F. (2001) Linkages among interest rates in the United States, Germany and Norway, Scadinavian Journal of Economics, 103(1), 127-145.

3. Browne, A. (2006) Currency reserves held by Beijing continues to soar, Wall Street Journal, January 16.

4. Chou, W. L. (2000) Exchange rate variability and China's exports, Journal of Comparative Economics, 28, 61-79.

5. $\quad$ Ender, W. (1995) Applied Econometric Times Series, John Wiley and Sons.

6. Engle, R. and Granger, C. W. J. (1987) Cointegration and error correction estimates: represnetation, estimation and testing, Econometrica LV: 251-276.

7. Goodman, P. (2006) China set to reduce exposure to dollar, Washington Post, Jan. 10.

8. Hanke, S. (2005) A contrarian view on China and its interest rates, Forbes Investors Advisory Financial Round tables discussion, October 27.

9. Jin, Z. (2003) The dynamics of real interest rates, real exchange rates and the balance of payments in China: 1980-2002, IMF Working Paper WP/03/67.

10. Krugman, P. (2005) The Chinese connection, New York Times, May 21. 
11. Lu, M and Zhang, Z (2003) Exchange rate reform and its inflationary consequences: an empirical analysis for China, Applied Economics, 35, 189-99.

12. Magg, J. (2005) A saving glut that won't last, National Journal, 37, 2134-2135.

13. Moosa, Imad (2008) Forecatsing the Chinese Yuan-Dollar exchange rate under the new Chinese exchange rte regime, International Journal of Business and Economics, Vol. 7, No. 1, 23-35.

14. Morrison, Wayne M., and Marc Labonte (2008) China's holdings of U.S. securities: Implications for the U.S. economy, CRS Report for Congress, May 19.

15. Narayan, P. K. (2006), Examining the relationship between trade balance and exchange rate: the case of China's trade with the USA, Applied Economics Letters, 13, 507-510.

16. Narayan, P. K. and Smyth, R. (2004) The relationship between the real exchange rates and the balance of payments: empirical evidence for China from cointegration and causality testing, Applied Economics Letters, 11, 287-291.

17. Navarro, Peter (2009) Undervalued currency helps, hurt U.S. economy, The San Francisco Chronicle, February 17.

18. Shostak, F. (2005) China does not determine U.S. interest rates, Mises Institute, June 3.

19. Wu, Tao (2005) The Long-term interest rate conundrum: Not unravled yet?, Federal Reserve Bank of San Francisco Economic Letter, No. 2005-08, April 29.

20. Xu, Y. (2000) China's exchange rate policy, China Economic Review, 11, 262-77.

21. Zhang, Z. (2001) Real exchange rates misalignment in China: an empirical investigation, Journal of Comparative Economics, 29, 80-94. 


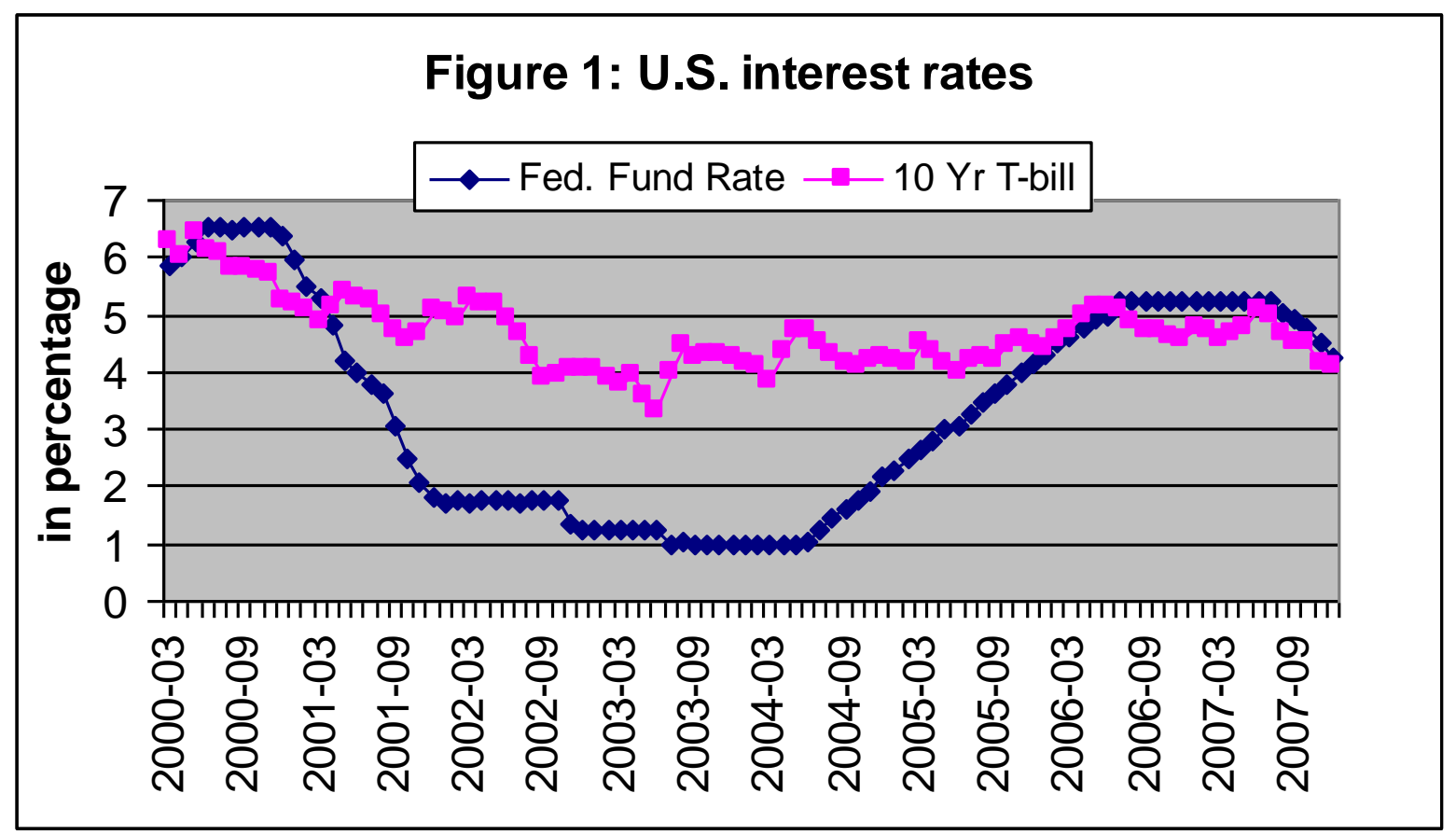

Source: Federal Reserve Board

\section{Figure 2: China's Trade with the U.S.}

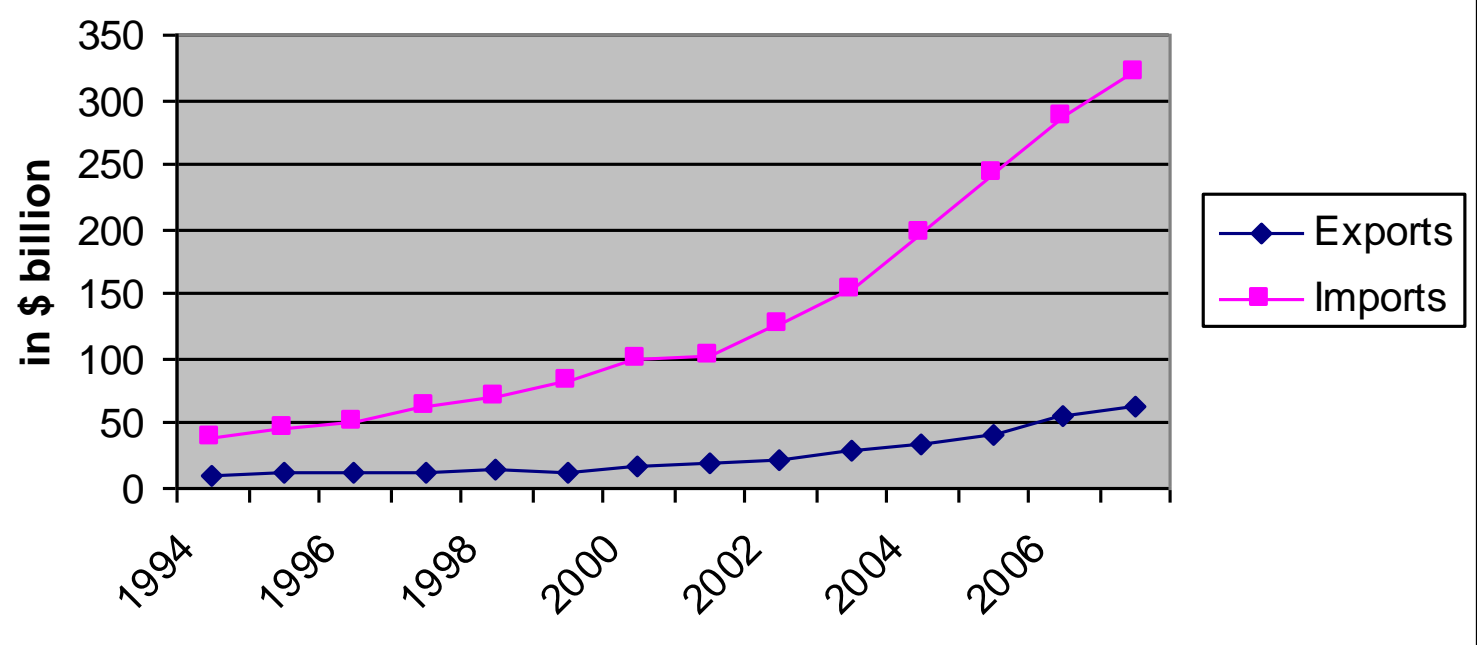

Source: U.S. Department of Commerce and Census Bureau 


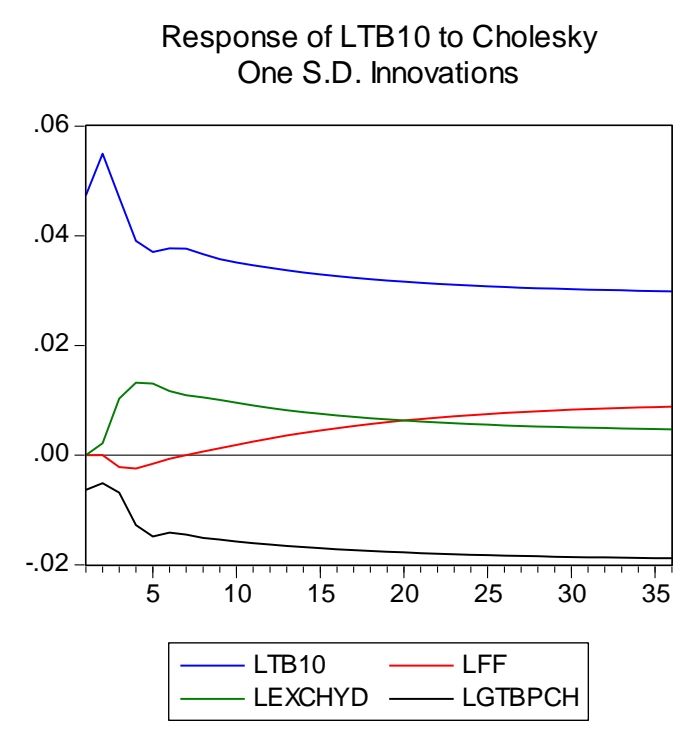

Response of LEXCHYD to Cholesky One S.D. Innovations

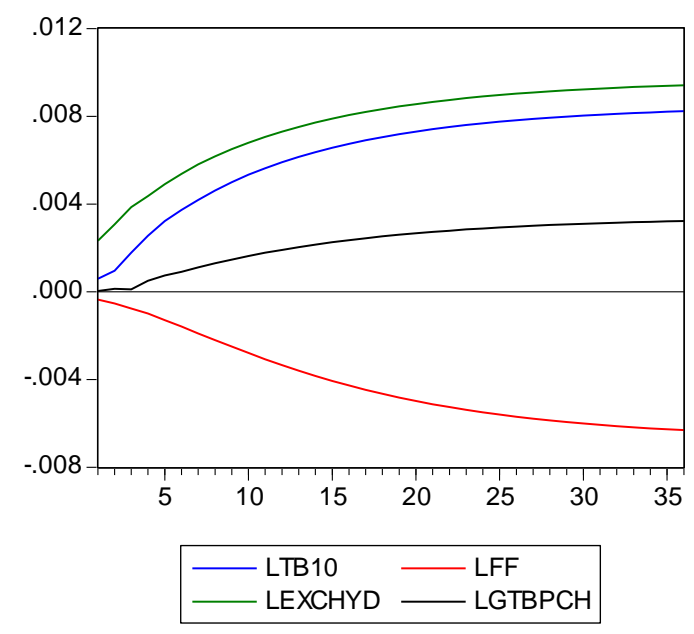

Response of LFF to Cholesky One S.D. Innovations

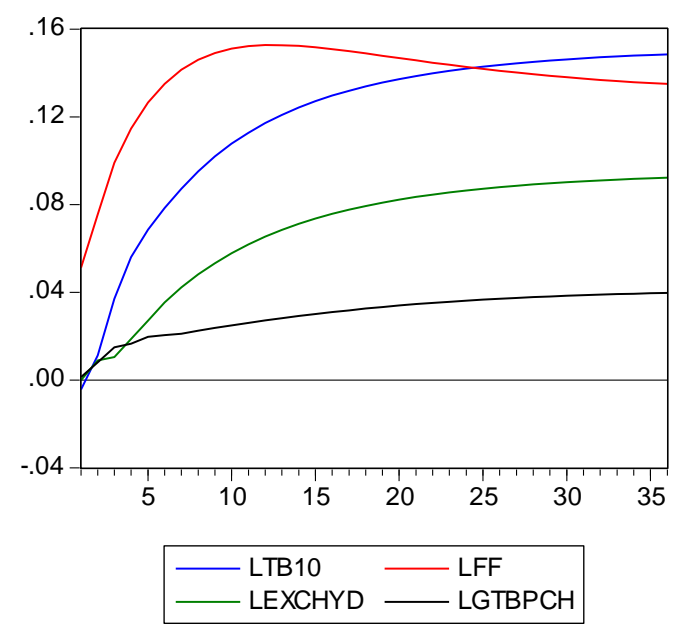

Response of LGTBPCH to Cholesky One S.D. Innovations

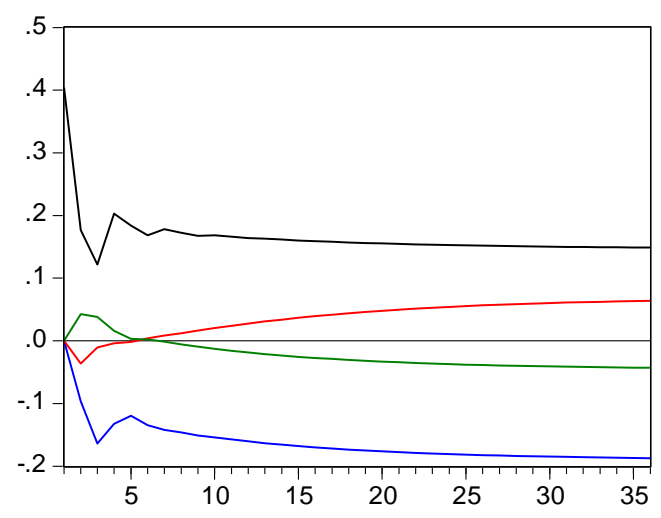

\begin{tabular}{|ll|}
\hline LTB10 & LFF \\
LEXCHYD & LGTBPCH \\
\hline
\end{tabular} 
Table 1: Breakdown of Major Foreign Holders of U.S. Securities ${ }^{\mathrm{a}}$ ( in US\$ billions)

\begin{tabular}{llllll}
\hline & $\begin{array}{l}\text { Dec. } \\
\mathbf{2 0 0 7}\end{array}$ & $\begin{array}{l}\text { Dec. } \\
\mathbf{2 0 0 5}\end{array}$ & $\begin{array}{l}\text { Dec. } \\
\mathbf{2 0 0 3}\end{array}$ & $\begin{array}{l}\text { Dec. } \\
\mathbf{2 0 0 1}\end{array}$ & $\begin{array}{l}\text { Dec. } \\
\mathbf{1 9 9 7}\end{array}$ \\
\hline Total & $2,353.2$ & $2,033.9$ & $1,523.1$ & $1,041.1$ & 1,278 \\
Japan & 581.2 & 670 & 550.8 & 317.7 & 300.7 \\
China & 477.6 & 310 & 159 & 78.6 & 47.3 \\
U.K. & 158.1 & 146 & 82.2 & 45 & 286.9 \\
Others & $1,136.3$ & 907.9 & 731.1 & 598.6 & 643.1 \\
\hline
\end{tabular}

Notes:

${ }^{\text {a }}$ : Estimated foreign holdings of U.S. Treasury marketable and non-marketable bills, bonds, and notes reported under the Treasury International Capital (TIC) reporting system are based on annual Surveys of Foreign Holdings of U.S. Securities and on monthly data.

b : United Kingdom includes Channel Islands and Isle of Man.

Table 2: Cointegration Test Results from the Johansen Maximum Likelihood Procedure

\begin{tabular}{llccc}
\hline Ho: & Trace & $\begin{array}{c}\text { Critical Vale } \\
(\mathbf{9 5 \% )}\end{array}$ & $\lambda$ max & $\begin{array}{c}\text { Critical value } \\
(\mathbf{9 5 \% )})\end{array}$ \\
\hline None & $51.5^{* *}$ & 47.86 & 23.38 & 27.58 \\
At most 1 & $28.12^{*}$ & 29.80 & 16.9 & 21.13 \\
At most 2 & 11.20 & 15.49 & 9.86 & 14.26 \\
At most 3 & 1.32 & 3.84 & 1.34 & 3.84 \\
\hline
\end{tabular}

Notes:

The trace statistic tests the null hypothesis that there are at most $r$ cointegrating vectors against the alternative of $r$ or more cointegrating vectors. Meanwhile, the maximum eigenvalue statistic tests for $r$ cointegrating vectors against the alternative of $(r+1)$ cointegrating vectors.

$* *$ and $*$ indicate rejection of null hypothesis of no integration at 5\% and $10 \%$ significance level, respectively.

Table 3: Vector Error Model Parameter Estimates ${ }^{\mathrm{a}}$

\begin{tabular}{lcccc}
\hline $\begin{array}{l}\text { Dependent } \\
\text { Variable }\end{array}$ & $\Delta L T B 10$ & $\Delta L F F$ & $\Delta L E X C H$ & $\Delta L T B P U R$ \\
\hline Constant & 0.00 & 0.00 & -0.00 & 0.06 \\
ECM & $-0.14^{* *}$ & 0.08 & $0.01^{* * *}$ & $-1.42^{* * *}$ \\
$\Delta L T B 10(-1)$ & $0.29 * * *$ & $0.25^{* * *}$ & -0.01 & -0.90 \\
$\Delta L T B 10(-2)$ & -0.09 & $0.32^{* * *}$ & 0.00 & -0.86 \\
$\Delta L F F(-1)$ & -0.01 & $0.51^{* * *}$ & -0.00 & -0.70 \\
$\Delta L F F(-2)$ & -0.03 & $0.24^{* * *}$ & 0.00 & 0.34 \\
$\Delta L E X C H(-1)$ & 1.07 & 3.76 & $0.31^{* * *}$ & 19.83 \\
$\Delta L E X C H(-2)$ & 3.11 & -3.22 & $0.23^{* *}$ & 9.13 \\
$\Delta L T B P U R(-1)$ & $0.02^{*}$ & 0.01 & -0.00 & $-0.41^{* * *}$ \\
$\Delta L T B P U R(-2)$ & 0.01 & 0.01 & $-0.001^{*}$ & $-0.32^{* * * *}$ \\
$\mathrm{R}^{2}$ & 0.14 & 0.61 & 0.57 & 0.34 \\
F-Statistics & 1.60 & $14.73^{* * *}$ & $12.88^{* * *}$ & $4.86^{* * *}$ \\
\hline Notes: & & & &
\end{tabular}

a: The LM test for autocorrelation was performed on the model and found that there was no residual autocorrlation problem at $5 \%$ significance level.

ECM refers to the error correction mechanism term that is normalized with respect to each variable.

LTB10 refers to log of 10-Year Treasury bill yield; LFF is log of federal funds rate; LEXCH refers to the log of Yuan/USDollar exchange rate; LTBP is the log of Chinese purchase of U.S. Treasury securities.

$* * *, * *$ and $*$ refer to the rejection of null hypothesis of no causality at $1 \%, 5 \%$ and $10 \%$ significance levels, respectively. 
Table 4: Variance Decomposition Results

Shock to:

$\underline{\text { LTB10 }} \underline{\underline{L F}} \quad \underline{\text { LEXCH }} \quad \underline{\text { LTBP }}$

Relative variation of LTB10 explained by innovations to the systems variables:

period

$\begin{array}{ll}1 & 98.22 \\ 6 & 90.03 \\ 12 & 85.27 \\ 24 & 79.9 \\ 36 & 76.33\end{array}$

0.00

0.11

0.15

1.10

2.24

0.00
4.52
5.13
4.32
3.62

1.78

5.370

9.44

14.66

17.81

Relative variation of LFF explained by innovations to the systems variables:

period

$\begin{array}{ll}1 & 0.72 \\ 6 & 18.3 \\ 12 & 26.45 \\ 24 & 33.87 \\ 36 & 37.48\end{array}$

99.21
77.15
65.08
53.03
46.90

0.00

0.067

1.60

1.61

2.04

37.48

46.90

11.06

2.41

Relative variation of LEXCH explained by innovations to the systems variables:

$\begin{array}{llllll}\text { period } & 1 & 5.85 & 2.11 & 91.94 & 0.01 \\ & 6 & 24.34 & 4.28 & 70.23 & 1.14 \\ & 12 & 31.06 & 7.92 & 58.43 & 2.59 \\ & 24 & 33.00 & 13.14 & 49.97 & 3.89 \\ & 36 & 33.01 & 15.79 & 46.80 & 4.40\end{array}$

Relative variation of LTBP explained by innovations to the systems variables:

\begin{tabular}{|c|c|c|c|c|c|}
\hline \multirow[t]{5}{*}{ perioc } & 1 & 0.00 & 0.00 & 0.00 & 100.0 \\
\hline & 6 & 21.33 & 0.36 & 0.88 & 77.43 \\
\hline & 12 & 31.30 & 0.52 & 0.62 & 67.56 \\
\hline & 24 & 41.53 & 1.96 & 1.12 & 55.38 \\
\hline & 36 & 46.21 & 3.30 & 1.66 & 48.88 \\
\hline
\end{tabular}

Notes:

LTB10 refers to log of 10-Year Treasury bill yield; LFF is log of s rate; LEXCH refers to the log of Yuan/USDollar exchange rate; LTBP is the log of Chinese purchase of U.S. Treasury securities. 


\section{NOTES}

